Article

\title{
New Hydroxydecanoic Acid Derivatives Produced by an Endophytic Yeast Aureobasidium pullulans AJF1 from Flowers of Aconitum carmichaeli
}

\author{
Hyun Gyu Choi ${ }^{1}$, Jung Wha Kim ${ }^{1}$, Hyukjae Choi ${ }^{2} \mathbb{D}$, Ki Sung Kang ${ }^{3}$ and Sang Hee Shim ${ }^{1, *}$ \\ 1 College of Pharmacy, Duksung Women's University, Seoul 01369, Korea; chg—@hanmail.net (H.G.C.); \\ jwkim7317@gmail.com (J.W.K.) \\ 2 College of Pharmacy, Yeungnam University, Gyeongsan 38541, Korea; h5choi@yu.ac.kr \\ 3 College of Korean Medicine, Gachon University, Seongnam 13120, Korea; kkang@gachon.ac.kr \\ * Correspondence: sangheeshim@duksung.ac.kr; Tel.: +82-2-901-8774
}

Received: 13 October 2019; Accepted: 7 November 2019; Published: 8 November 2019

\begin{abstract}
Endophytes have been recognized as a source for structurally novel and biologically active secondary metabolites. Among the host plants for endophytes, some medicinal plants that produce pharmaceuticals have been reported to carry endophytes, which could also produce bioactive secondary metabolites. In this study, the medicinal plant Aconitum carmichaeli was selected as a potential source for endophytes. An endophytic microorganism, Aureobasidium pullulans AJF1, harbored in the flower of Aconitum carmichaeli, was cultured on a large scale and extracted with an organic solvent. Extensive chemical investigation of the extracts resulted in isolation of three lipid type compounds (1-3), which were identified to be $(3 R, 5 R)-3,5$-dihydroxydecanoic acid (1), (3R,5R)-3-(((3R,5R)-3,5-dihydroxydecanoyl)oxy)-5-hydroxydecanoic acid (2), and (3R,5R)-3-

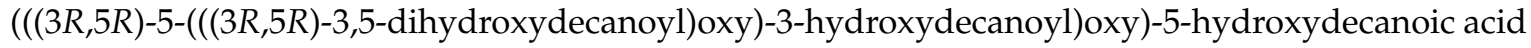
(3) by chemical methods in combination with spectral analysis. Compounds 2 and 3 had new structures. Absolute configurations of the isolated compounds (1-3) were established using modified Mosher's method together with analysis of NMR data for their acetonide derivatives. All the isolates (1-3) were evaluated for antibiotic activities against Escherichia coli, Staphylococcus aureus, Bacillus subtilis, Pseudomonas aeruginosa, and their cytotoxicities against MCF-7 cancer cells. Unfortunately, they showed low antibiotic activities and cytotoxic activities.
\end{abstract}

Keywords: endophyte; Aureobasidium pullulans; hydroxydecanoic acid; Aconitum carmichaeli

\section{Introduction}

Endophytes spend all or part of their lives colonizing inside of healthy tissues of a host plant. They cause no apparent disease symptoms in host plant, and rather give abilities including tolerance to biotic and abiotic stress, nutrient acquisition, and plant growth promotion to the host plant [1]. Various types of secondary metabolites with significant bioactivities have been produced by endophytes as a result of interaction with host plant [2]. Biosynthesis of many metabolites has been considered to be caused by a result of environmental signals such as insects and plant pathogen [3]. In a search for endophytes to produce secondary metabolites with intriguing structures and potent bioactivities, an endophytic yeast Aureobasidium pullulans AJF1 was isolated from flowers of Aconitum carmichaeli. Some studies have revealed that A. pullulans produce various types of metabolites such as polysaccharides, mannitol oils, poly malic acid, 2-propylacrylic acid, 8,9-dihydroxy-2-methyl-4H,5H-pyrano[3,2-c]chromon-4-one, 2-methylenesuccinic acid, hexane-1,2,3,5,6-hexol, etc. [4-7]. Roots of Aconitum carmichaeli Debeaux have been treated as one of the important crude drugs in oriental medicine due to its potent activities to treat shock 
caused by acute and chronic heart failure and low blood pressure as well as toxicities [8]. Even though a broad spectrum of research on the secondary metabolites produced by endophytes from medicinal plants has been carried out since discovery of paclitaxel production by the endophytic fungus, Taxomyces andreanae $[9,10]$, only a few studies have been conducted on the endophytes isolated from A. carmichaeli [11-13]. Herein, three metabolites (1-3) were isolated from cultures of the endophytic yeast $A$. pullulans AJF1 and investigated for their activities (Figure 1). They were all hydroxy fatty acid derivatives and compound 1,3,5-dihydroxydecanoic acid, was previously reported to be one of main components of extracellular lipids produced by Aureobasidium sp. [14]. However, its absolute as well as relative stereochemistry was elucidated for the first time in this study.
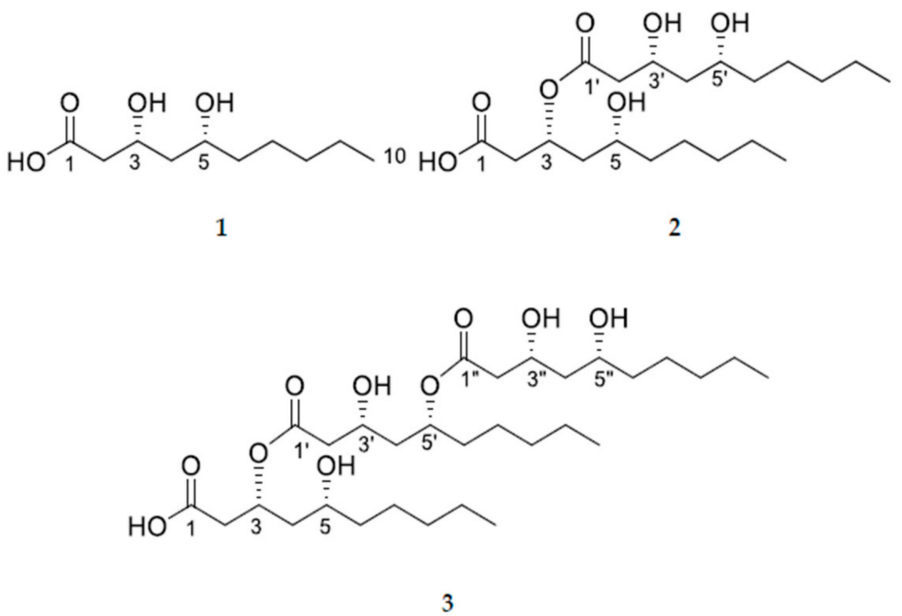

Figure 1. Structures of (3R,5R)-3,5-dihydroxydecanoic acid (1), (3R,5R)-3-(((3R,5R)-3,5-dihydroxy decanoyl)oxy)-5-hydroxydecanoic acid (2), and (3R,5R)-3-(((3R,5R)-5-(((3R,5R)-3,5-dihydroxydecan oyl)oxy)-3-hydroxydecanoyl)oxy)-5-hydroxydecanoic acid (3).

\section{Results and Discussion}

Three hydroxy fatty acid derivatives were isolated from cultures of an endophytic yeast strain of Aureobasidium pullulans AJF1. Mass cultivation of the strain, extraction, followed by a series of chromatographic methods led to the isolation of three metabolites (1-3). Their chemical structures were determined to be $(3 R, 5 R)-3,5$-dihydroxydecanoic acid (1), $(3 R, 5 R)-3-(((3 R, 5 R)-3,5-$ dihydroxydecanoyl)oxy)-5-hydroxydecanoic acid (2), and (3R,5R)-3-(((3R,5R)-5- $(((3 R, 5 R)-3,5-$ dihydroxydecanoyl)oxy)-3-hydroxydecanoyl)oxy)-5-hydroxydecanoic acid (3) by spectroscopic data analyses such as NMR and MS together with a variety of chemical reactions.

Compound 1 was isolated as colorless oil. The molecular formula was determined to be $\mathrm{C}_{10} \mathrm{H}_{20} \mathrm{O}_{4}$ from positive HRFABMS at $m / z$ 187.1331 $\left[\mathrm{M}-\mathrm{H}_{2} \mathrm{O}+\mathrm{H}\right]^{+}$(Calcd for $\left.\mathrm{C}_{10} \mathrm{H}_{19} \mathrm{O}_{3}, 187.1329\right)$. ${ }^{1} \mathrm{H}-\mathrm{NMR}$ of compound 1 showed two oxygenated methines at $\delta_{\mathrm{H}} 4.66(\mathrm{dtd}, J=11.3,5.3,3.1 \mathrm{~Hz})$ and 4.33 (quint, $J=3.7 \mathrm{~Hz})$, a terminal methyl at $\delta_{\mathrm{H}} 0.85(\mathrm{t}, J=6.9 \mathrm{~Hz})$, together with several methylene signals. Its ${ }^{13} \mathrm{C}-\mathrm{NMR}$ spectrum exhibited the presence of ten carbons including a carboxylic carbon at $\delta_{\mathrm{C}}=171.2$, two oxymethine carbons at $\delta_{C} 76.1$ and 62.5 , six methylene carbons at $\delta_{C} 38.5,35.7,35.4,31.5,24.5$, and 22.5, and a terminal methyl carbon at $\delta_{C} 13.9$, suggesting that compound 1 was a dihydroxy decanoic acid. The positions of two hydroxyl groups were confirmed by 2D-NMR data including ${ }^{1} \mathrm{H}-{ }^{1} \mathrm{H}$ COSY, HSQC, and HMBC. A C-CH $-\mathrm{CH}(\mathrm{O})-\mathrm{CH}_{2}-\mathrm{CH}(\mathrm{O})$ spin system was obtained by analysis of its ${ }^{1} \mathrm{H}-{ }^{1} \mathrm{H}$ COSY spectrum (Figure 2). HMBC correlations of the methylene protons at $\delta_{\mathrm{H}} 2.67$ and 2.58 with the carboxylic carbon $\left(\delta_{C} 171.2\right)$, oxymethine carbon $\left(\delta_{C} 62.5\right)$, and a methylene carbon $\left(\delta_{C} 35.7\right)$ indicated that the spin system was directly linked to carboxylic acid, that is, 3,5-dihydroxy decanoic acid (Figure 1). This structure was further confirmed by HMBC correlations of the oxymethine proton at $\delta_{\mathrm{H}} 4.33$ with the carboxylic carbon, two methylene carbons $\left(\delta_{\mathrm{C}} 38.5\right.$ and 35.7$)$, and the oxymethine carbon $\left(\delta_{\mathrm{C}} 76.1\right)$. 
Compound 2 was isolated as colorless oil. Its molecular formula was established to be $\mathrm{C}_{20} \mathrm{H}_{38} \mathrm{O}_{7}$ on the basis of positive HRFABMS at $m / z 373.2590\left[\mathrm{M}-\mathrm{H}_{2} \mathrm{O}+\mathrm{H}\right]^{+}$(Calcd for $\left.\mathrm{C}_{20} \mathrm{H}_{37} \mathrm{O}_{6}, 373.2585\right)$. ${ }^{1} \mathrm{H}$ and ${ }^{13} \mathrm{C}$-NMR spectra of compound 2 were similar to those for compound $\mathbf{1}$, differing in that compound 2 has ten more carbons including two more oxymethine groups and one more carboxylic acid than 1 (Table 1). Two units of $\mathrm{C}-\mathrm{CH}_{2}-\mathrm{CH}(\mathrm{O})-\mathrm{CH}_{2}-\mathrm{CH}(\mathrm{O})$ spin system were observed in its ${ }^{1} \mathrm{H}-{ }^{1} \mathrm{H} \mathrm{COSY}$ spectrum (Figure 1). Thus, it was presumed that two units of dihydroxy fatty acid might be esterified to form compound 2, which was supported by the downfield shifted oxymethine proton signal $\left(\delta_{\mathrm{H}}\right.$ 5.27). The connection of two units was verified by HMBC correlations. HMBC correlations of the oxymethine proton at $\delta_{\mathrm{H}} 5.27$ with a carboxylic acid carbon $\left(\delta_{\mathrm{C}} 169.2\right)$, a carboxylic ester carbon $\left(\delta_{\mathrm{C}}\right.$ $171.1)$, and two methylene carbons $\left(\delta_{C} 35.3\right.$ and 32.7$)$ supported that one dihydroxy fatty acid moiety was esterified to the other dihydroxy fatty acid moiety at the C-3 position (Figure 1). The possibility that two dihydroxy fatty acids might have different carbon numbers was not excluded. However, the presence of two decanoic acid moieties was confirmed by ten carbon atoms observed in the ${ }^{13} \mathrm{C}-\mathrm{NMR}$ spectrum for hydrolysate of compound 2 . Thus the planar structure of compound 2 was elucidated to be 3-((3,5-dihydroxydecanoyl)oxy)-5-hydroxydecanoic acid.

Table 1. ${ }^{1} \mathrm{H}$ and ${ }^{13} \mathrm{C}-\mathrm{NMR}$ data of 2 and 3 ( $\delta$ values). ${ }^{\mathrm{a})}$

\begin{tabular}{|c|c|c|c|c|}
\hline \multirow{2}{*}{ No. } & \multicolumn{2}{|l|}{2} & \multicolumn{2}{|l|}{3} \\
\hline & $\delta_{\mathrm{H}}(\mathrm{m}, J \text { in } \mathrm{Hz})^{b)}$ & $\delta_{C}{ }^{c)}$ & $\delta_{\mathrm{H}}(\mathrm{m}, J \text { in } \mathrm{Hz})^{\mathrm{b})}$ & $\delta_{C}{ }^{c)}$ \\
\hline 1 & & 169.2 & & 169.0 \\
\hline $2 \mathrm{a} 2 \mathrm{~b}$ & $\begin{array}{c}2.77(\mathrm{dd}, J=18.1,5.4 \mathrm{~Hz}) \\
2.69(\mathrm{ddd}, J=18.1,3.5,1.6 \mathrm{~Hz})\end{array}$ & 35.3 & $\begin{array}{c}2.76(\mathrm{dd}, 18.1,5.3) \\
2.68(\mathrm{ddd}, 18.1,3.5,1.6)\end{array}$ & 35.3 \\
\hline 3 & $5.27(\mathrm{dt}, J=7.0,3.5 \mathrm{~Hz})$ & 65.7 & $5.26(\mathrm{dq}, 7.2,3.5)$ & 66.1 \\
\hline $4 \mathrm{a} 4 \mathrm{~b}$ & $\begin{array}{r}2.07(\mathrm{dtd}, J=14.9,3.5,1.6 \mathrm{~Hz}) \\
1.77(\mathrm{ddd}, J=14.9,11.5,3.5 \mathrm{~Hz})\end{array}$ & 32.7 & $\begin{array}{c}2.07(\mathrm{dtd}, 14.9,3.5,1.6) \\
1.76(\mathrm{ddd}, 14.9,12.3,4.0)\end{array}$ & 32.8 \\
\hline 5 & $\begin{array}{c}4.53(\mathrm{dtd}, J=11.5,5.0,2.9 \mathrm{~Hz}) \\
1.69(\mathrm{dddd}, J=13.5,10.2,7.5\end{array}$ & 76.1 & $4.53(\mathrm{dtd}, 11.1,4.9,3.1)$ & 76.2 \\
\hline $6 a 6 b$ & $\begin{array}{r}5.0 \mathrm{~Hz}) \\
1.57(\mathrm{~m})\end{array}$ & 35.2 & $0.55(\mathrm{~m})$ & 34.7 \\
\hline $7 \mathrm{a} b \mathrm{~b}$ & $\begin{array}{l}1.46(\mathrm{~m}) \\
1.37(\mathrm{~m})\end{array}$ & 24.3 & $\begin{array}{l}1.47(\mathrm{~m}) \\
1.36(\mathrm{~m})\end{array}$ & 24.4 \\
\hline 8 & $1.27(\mathrm{~m})$ & 31.7 & $1.25(\mathrm{~m})$ & 31.8 \\
\hline 9 & $1.35(\mathrm{~m})$ & 22.5 & $1.35(\mathrm{~m})$ & 22.5 \\
\hline 10 & $0.86(\mathrm{t}, J=6.9 \mathrm{~Hz})$ & 13.9 & $0.86(t, 6.9)$ & 14.0 \\
\hline $1^{\prime}$ & & 171.1 & & 171.5 \\
\hline $2^{\prime} \mathrm{a} 2^{\prime} \mathrm{b}$ & $\begin{array}{l}2.48(\mathrm{~m}) \\
2.48(\mathrm{~m})\end{array}$ & 42.2 & $\begin{array}{l}2.52(\mathrm{dd}, 16.1,3.6) \\
2.45(\mathrm{~m})\end{array}$ & 41.7 \\
\hline $3^{\prime}$ & $4.25(\mathrm{ddt}, 9.4,7.5,5.1)$ & 68.9 & $4.10(\mathrm{tt}, 8.2,4.0)$ & 66.3 \\
\hline $4^{\prime} \mathrm{a} 4^{\prime} \mathrm{b}$ & $\begin{array}{l}1.56(\mathrm{~m}) \\
1.54(\mathrm{~m})\end{array}$ & 42.0 & $\begin{array}{l}1.83(\mathrm{~m}) \\
1.64(\mathrm{~m})\end{array}$ & 41.0 \\
\hline $5^{\prime}$ & $3.85(\mathrm{ddd}, 12.1,7.5,4.5)$ & 72.3 & $5.04(\mathrm{tt}, 8.9,4.8)$ & 72.9 \\
\hline $6^{\prime} \mathrm{a} 6^{\prime} \mathrm{b}$ & $\begin{array}{l}1.45(\mathrm{~m}) \\
1.41(\mathrm{~m})\end{array}$ & 37.8 & $\begin{array}{l}1.68(\mathrm{~m}) \\
1.57(\mathrm{~m})\end{array}$ & 35.4 \\
\hline $7^{\prime} \mathrm{a} 7^{\prime} \mathrm{b}$ & $\begin{array}{l}1.46(\mathrm{~m}) \\
1.37(\mathrm{~m})\end{array}$ & 24.9 & $\begin{array}{l}1.47(\mathrm{~m}) \\
1.36(\mathrm{~m})\end{array}$ & 24.8 \\
\hline $8^{\prime}$ & $1.25(\mathrm{~m})$ & 31.4 & $1.25(\mathrm{~m})$ & 31.5 \\
\hline $9^{\prime}$ & $1.27(\mathrm{~m})$ & 22.4 & $1.35(\mathrm{~m})$ & 22.5 \\
\hline $10^{\prime}$ & $0.86(t, 6.9)$ & 13.9 & $0.86(t, 6.9)$ & $\begin{array}{c}14.0 \\
172.3\end{array}$ \\
\hline $2^{\prime \prime} \mathrm{a} 2^{\prime \prime} \mathrm{b}$ & & & $\begin{array}{l}2.45(\mathrm{~m}) \\
2.40(\mathrm{~m})\end{array}$ & $\begin{array}{l}1 / 2.3 \\
42.7\end{array}$ \\
\hline $3^{\prime \prime}$ & & & $4.25(\mathrm{tt}, 8.5,4.0)$ & 69.8 \\
\hline $4^{\prime \prime} \mathrm{a} 4^{\prime \prime} \mathrm{b}$ & & & $1.55(\mathrm{~m})$ & 42.4 \\
\hline $5^{\prime \prime}$ & & & $3.84(\mathrm{tt}, 8.1,4.1)$ & 72.4 \\
\hline $6^{\prime \prime} \mathrm{a} 6^{\prime \prime} \mathrm{b}$ & & & $\begin{array}{l}1.44(\mathrm{~m}) \\
1.55(\mathrm{~m})\end{array}$ & 37.9 \\
\hline $7^{\prime \prime} \mathrm{a} 7^{\prime \prime} \mathrm{b}$ & & & $\begin{array}{l}1.37(\mathrm{~m}) \\
1.26(\mathrm{~m})\end{array}$ & 25.0 \\
\hline $8^{\prime \prime}$ & & & $1.25(\mathrm{~m})$ & 31.5 \\
\hline $9^{\prime \prime}$ & & & $1.27(\mathrm{~m})$ & 22.5 \\
\hline $10^{\prime \prime}$ & & & $0.86(t, 6.9)$ & 14.0 \\
\hline
\end{tabular}

\footnotetext{
$\mathrm{MHz}$ ) NMR measured in $\mathrm{CDCl}_{3}$.
} 
Compound 3 was also isolated as colorless oil. Its molecular formula was established to be $\mathrm{C}_{30} \mathrm{H}_{56} \mathrm{O}_{10}$ from the positive HRFABMS at $m / z 581.3657\left[\mathrm{M}-\mathrm{H}_{2} \mathrm{O}+\mathrm{Na}\right]^{+}$(Calcd for $\mathrm{C}_{30} \mathrm{H}_{54} \mathrm{O}_{9} \mathrm{Na}_{\text {, }}$ 581.3660). The ${ }^{1} \mathrm{H}$ and ${ }^{13} \mathrm{C}-\mathrm{NMR}$ of compound 3 were also similar to those for compound 2 (Table 1 ). As in the cases of compounds 1 and 2 , ten more carbons including two additional oxymethines $\left(\delta_{C} 69.8\right.$ and 72.4), one more carboxylic ester carbon $\left(\delta_{C} 172.3\right)$, six methylene carbons $\left(\delta_{C} 42.7,42.4,37.9,25.0\right.$, $31.5,22.5)$, and a terminal methyl group $\left(\delta_{C} 14.0\right)$ appeared compared with compound 2 , suggesting that three dihydroxy fatty acid moieties were linked together through ester linkage. The positions of the esterification were confirmed by HMBC correlations (Figure 2). HMBC correlations of the oxymethine $\mathrm{H}-3$ at $\delta_{\mathrm{H}} 5.29$ with a carboxylic acid carbon $\mathrm{C}-1$ at $\delta_{\mathrm{C}} 171.5$ and a carboxylic ester carbon $C-1^{\prime}$ at $\left.\delta_{C} 169.0\right)$ indicated that one dihydroxy fatty acid was esterified at the C-3 position of another dihydroxy fatty acid moiety. In addition, $\mathrm{HMBC}$ correlations of the oxymethine $\mathrm{H}-5^{\prime}$ at $\delta_{\mathrm{H}} 5.04$ with the last carboxylic ester carbon at $\delta_{C} 172.3$ and the oxymethine carcon $C-3^{\prime}$ at $\delta_{C} 66.3$ indicated that the last dihydroxy fatty acid moiety was esterified to $\mathrm{C}-5^{\prime}$ position of one of the dihydroxy fatty acid moiety. As shown in compound 2, the ${ }^{13} \mathrm{C}-\mathrm{NMR}$ spectrum of hydrolysate of compound 3 indicated the presence of three dihydroxy decanoic acids, suggesting the planar structure of compound 3.

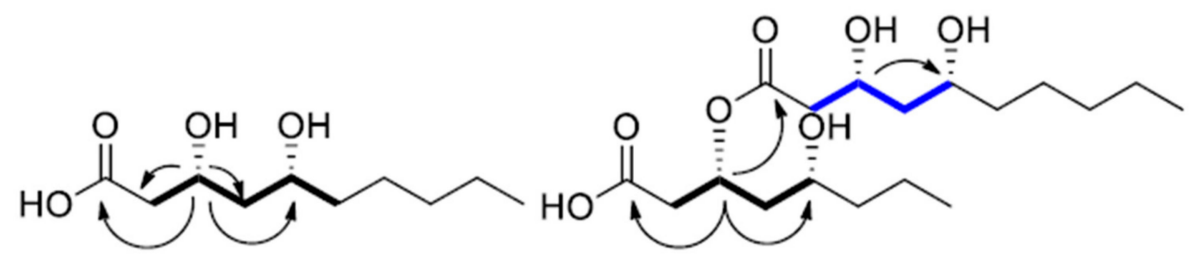

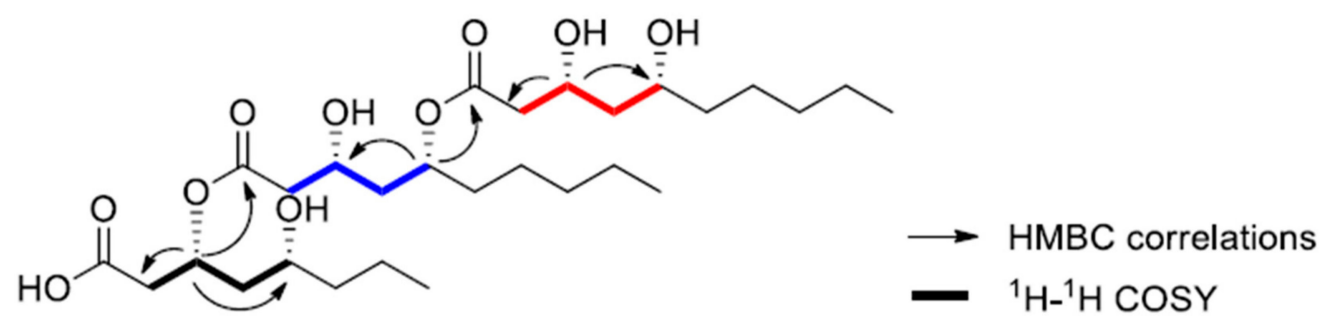

Figure 2. Key HMBC correlations for compounds 1-3 and ${ }^{1} \mathrm{H}-{ }^{1} \mathrm{H}$ COSY correlations.

Relative configurations of compounds 1-3 were determined on the basis of semi-synthetic structure modification and their spectroscopic data analyses. The relative configuration of the acyclic 1,3-diols in compounds 1-3 were assigned by using the $\left[{ }^{13} \mathrm{C}\right]$ acetonide method [15]. Compound 2 was hydrolyzed with $1 \mathrm{~N} \mathrm{HCl}$ in $\mathrm{MeOH}$ to yield the 3,5-dihydroxydecanoic acid methyl ester (2a) and 3,5-dihydroxydecanoic acid (2b) as depicted in Figure 3. Analogous treatment of compound 3 also afforded the 3,5-dihydroxydecanoic acid methyl ester (3a) and 3,5-dihydroxydecanoic acid (3b). Treatments of $\mathbf{1}, \mathbf{2 a}, \mathbf{2 b}, \mathbf{3 a}$, and $\mathbf{3 b}$ with 2,2-dimethoxypropane and pyridinium- $p$-toluensulfonate in methanol afforded the acetone ketal (1a, 2c, and 3c) at their 1,3-diol positions (Figure 3). Two methyl resonances observed at $\delta_{C} 30.1$ and 19.7 for the acetone ketals suggested the relative configurations of the 1,3-diol to be in syn configurations. Modified Mosher's method was employed to determine the absolute configurations of hydroxyl groups in these compounds. Treatment of $\mathbf{1}$ with $(R)$ and (S)-MTPA-Cl and a catalytic amount of DMAP (4-dimethylaminopyridine) in pyridine- $d_{5}$ afforded its $(S)$ and $(R)$-MTPA ester, respectively. Low field shifted proton resonance at $\delta_{\mathrm{H}} 4.33$ for $\mathrm{H}-3$ implied that the $(R)$ and $(S)$-MTPA-Cl reacted only with the hydroxyl group at the C-3 position not that 
at C-5. Analysis of ${ }^{1} \mathrm{H}-\mathrm{NMR}$ chemical shift differences $\left(\Delta \delta_{S-R}\right)$ between $(R)$ and $(S)$ Mosher's ester of 1 revealed the absolute configuration of C-3 and C-5 to be $R$ and $R$, respectively, as shown in Figure 2. Consequently, the structure of $\mathbf{1}$ was determined to be (3R,5R)-3,5-dihydroxydecanoic acid. Likewise, compound 2 was derivatized to its $(R)$ and (S)-MTPA ester using $(S)$ and $(R)$-MTPA-Cl, respectively, in which MTPA groups were confirmed to be attached to all the hydroxyl groups of compound 2 by chemical shifts of oxymethine protons. Analysis of ${ }^{1} \mathrm{H}-\mathrm{NMR}$ chemical shift differences $\left(\Delta \delta_{S-R}\right)$ between $(R)$ and $(S)$ tri-Mosher's ester of 2 revealed that $C-3,5,3^{\prime}$, and $5^{\prime}$ were all in $R$ configurations as shown. Thus, compound 2 was identified to be $(3 R, 5 R)-3-(((3 R, 5 R)-3,5-\mathrm{dih}$ ydroxydecanoyl)oxy)-5-hydroxydecanoic acid. Determination of the absolute configurations of $\mathbf{3}$ using Mosher's method was quite challenging since the proton resonances for methylene groups neighboring oxymethines were too difficult to be distinguished from others since many proton resonances were overlapped [16]. Nevertheless, Mosher's esterification of the hydrolysates of compound 3 allowed the determination of the absolute stereochemistry, since compound 3 was composed of three units of 3,5-dihydroxydecanoic acid moiety. To obtain each monomer of compound 3 , the acetonide derivative $3 \mathrm{C}$ was treated with pyridinium- $p$-toluensulfonate at $40{ }^{\circ} \mathrm{C}$ in $\mathrm{MeOH}$ to afford $3 \mathrm{~d}$. Analysis of ${ }^{1} \mathrm{H}-\mathrm{NMR}$ chemical shift differences $\left(\Delta \delta_{S-R}\right)$ of $(S)$ and $(R)$ esters of 3d elucidated the absolute configuration of C-3 and 5 to be $R$ and $R$ configurations, respectively (Figure 4). Finally, chemical structure of 3 was determined as (3R,5R)-3-(((3R,5R)-5-(((3R,5R)-3,5-dihydroxydecanoyl)oxy)-3-hydroxydecanoyl)oxy)-5 -hydroxydecanoic acid.

[A]<smiles>CCCCCCC[C@H](CC(=O)O)OC(=O)C(O)CC(O)C[C@H](O)CCCCC</smiles>

2

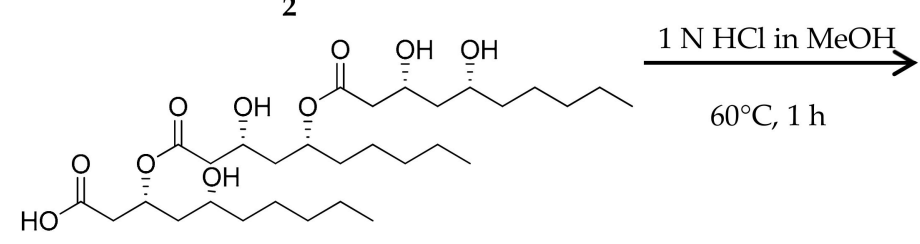

3

[B]

$$
\begin{aligned}
& \text { 篮 } \\
& 1,2 b, 3 b \\
& \overbrace{}^{O}
\end{aligned}
$$

[C]

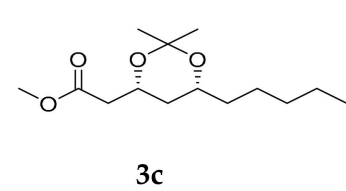

Pyridinium-

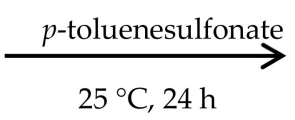

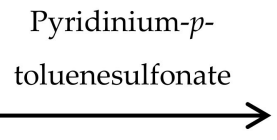

$40{ }^{\circ} \mathrm{C}, 1 \mathrm{~h}$

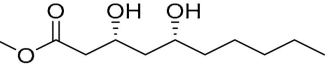

$2 a, 3 a$

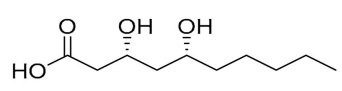

$2 b, 3 b$

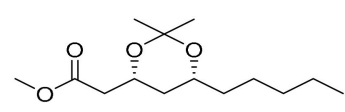

1a, 2c, 2d, 3c

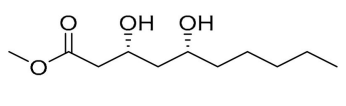

$3 d$

Figure 3. Reaction procedures for elucidation of stereochemistry for compounds 1-3; (A) hydrolysis of compounds $\mathbf{2}$ and $\mathbf{3}$; (B) synthesis of 1,3-diol-acetonides for $\mathbf{1}, \mathbf{2} \mathbf{b}, \mathbf{3} \mathbf{b}, \mathbf{2} \mathbf{a}$, and $\mathbf{3 a}$; and (C) deprotection of acetonide for $3 c$. 


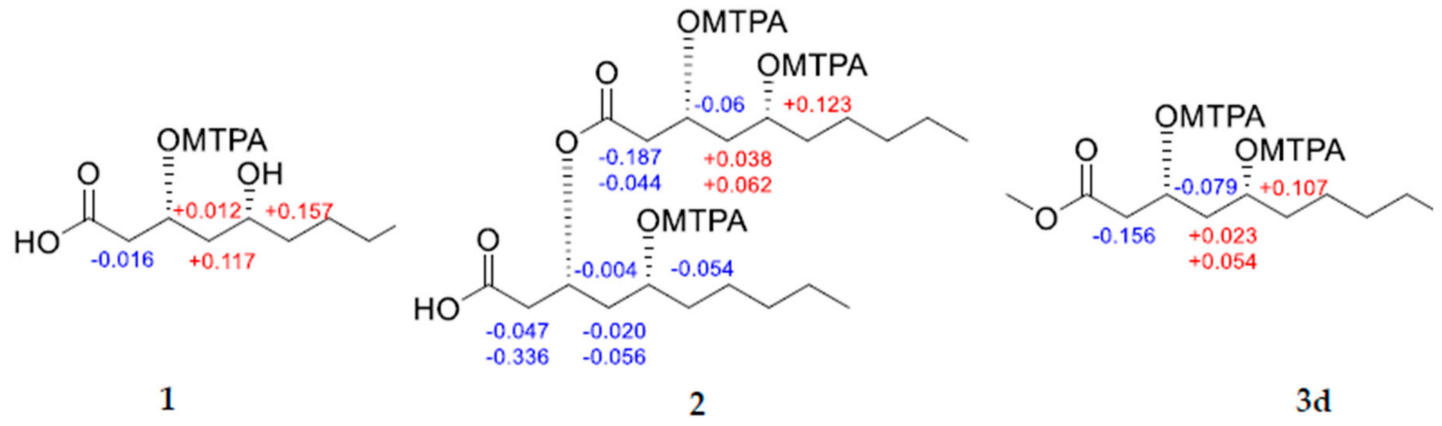

Figure 4. Observed chemical shift differences $\left(\Delta \delta_{S-R}=\delta_{S}-\delta_{R}\right.$, in ppm, $\left.500 \mathrm{MHz}\right)$ for the $R$ - and S-MTPA esters of compounds 1, 2, and 3d.

Compound 1, (3R,5R)-3,5-dihydroxydecanoic acid was previously reported as a not only synthetic intermediate but also natural product [14,17]. 3,5-Dihydroxydecanoic acid was reported to be a main component of the lipophilic moieties in lipid produced by Auresobasidium sp. [14]. However, its relative and absolute stereochemistry was established in this study for the first time. The (3R,5R)-3,5-dihydroxydecanoic acid moiety is extremely rare in nature. As one example of natural compounds to bear this moiety, exophilin A was isolated from a marine microorganism Exophiala pisciphila [18]. Exophilin A is also a trimer of the (3R,5R)-3,5-dihydroxydecanoic acid with the ester linkages at $5-\mathrm{OH}$ and $5^{\prime}-\mathrm{OH}$ while the esters in compound 3 at 3 and $5^{\prime}$. The relative and absolute stereochemistry of exophilin A were elucidated by comparison of the optical rotation value for its hydrolysate with that for (3R,5R)-3-hydroxy-5-decanolide [18]. In this study, the acetonide method, Mosher's method, and acid hydrolysis together with NMR analysis were employed to elucidated the stereochemistry of the isolated compounds. All the isolates (1-3) were evaluated for antibiotic activities against Escherichia coli, Staphylococcus aureus, Bacillus subtilis, Pseudomonas aeruginosa, and their cytotoxicities against MCF-7 cancer cells. Unfortunately, they showed low antibiotic activeities and cytotoxic activities. While exophilin A was reported to be active against Staphylococcus aureus with an MIC of $50 \mu \mathrm{g} / \mathrm{mL}$, compound 3 did not show antibacterial activities even at $128 \mu \mathrm{g} / \mathrm{mL}$.

\section{Materials and Methods}

\subsection{General Experimental Procedures}

The high-resolution fast atom bombardment mass spectrometry (HRFABMS) data were obtained on gas chromatography high resolution mass spectrometer (JMS-700, Jeol, Tokyo, Japan). The nuclear magnetic resonance (NMR) spectra were acquired with a 300 Ultra shield spectrometer $\left({ }^{1} \mathrm{H}, 300 \mathrm{MHz}\right.$; ${ }^{13} \mathrm{C}$, $75 \mathrm{MHz}$; Bruker, Billerica, MA, USA), a NMR system $500 \mathrm{MHz}\left({ }^{1} \mathrm{H}, 500 \mathrm{MHz} ;{ }^{13} \mathrm{C}, 125 \mathrm{MHz}\right.$, Varian, Palo Alto, CA, USA), using the solvent signals $\left(\delta_{\mathrm{H}} 7.24 / \delta_{\mathrm{C}} 77.00\right.$ for $\mathrm{CDCl}_{3}$; Cambridge Isotope Laboratories, Inc., Tewksbury, MA, USA) as internal standards; chemical shifts are indicated as $\delta$ values. Column chromatography was performed over silica gel 60 (70-230 mesh, Merck, Darmstadt, Germany). Silica gel 60 F254 and RP-18 F254S plates (Merck) were used for analysis by thin-layer chromatography (TLC) under detection of ultraviolet (UV) and $10 \% \mathrm{H}_{2} \mathrm{SO}_{4}$ reagent to visualize the compounds. The analytical grade of solvents was used for the whole experiments.

\subsection{Fungal Materials}

AJF1 was isolated from the flowers of Aconitum carmichaeli collected from Jangbaek Mountain, Gangwon-do, South Korea, in 2016. The collected flowers were sterilized with $70 \%$ ethanol for $1 \mathrm{~min}$ and $7 \% \mathrm{H}_{2} \mathrm{O}_{2}$ for $1 \mathrm{~min}$, and then washed with sterilized distilled water. The sterilized flowers were cut into small pieces, and then diluted with sterilized water. The diluted solution was poured onto YME agar media (Yeast Ex, $4 \mathrm{~g} / \mathrm{L}$; Malt Ex, $10 \mathrm{~g} / \mathrm{L}$; Dextrose, $4 \mathrm{~g} / \mathrm{L}$; and sterilized water 1L), which was then incubated at $28^{\circ} \mathrm{C}$ for 1 month. A pure strain of incarnadine colored colony (AJF1) was obtained 
and the strain AJF1 was identified to be Aureobasidium pullulans based on 16S/18S rDNA sequence analysis (97.72\%, similarity to Aureobasidium pullulans strain YY20).

\subsection{Extraction and Isolations}

The yeast strain was inoculated in $36 \mathrm{~L}$ of YME media (Yeast Ex, $4 \mathrm{~g} / \mathrm{L}$; Malt Ex, $10 \mathrm{~g} / \mathrm{L}$; Dextrose, 4 $\mathrm{g} / \mathrm{L}$; and sterilized water $1 \mathrm{~L}$ ) at $25^{\circ} \mathrm{C}$ for 10 days at $150 \mathrm{rpm}$. The cultured media of the strain $(36 \mathrm{~L})$ was extracted with EtOAc twice $(36 \mathrm{~L} \times 2)$ and the EtOAc layer was concentrated in vacuo to give crude extracts $(7.9 \mathrm{~g})$. The EtOAc extract $(7.9 \mathrm{~g})$ was subjected to vacuum liquid chromatography (VLC, $40 \mathrm{~cm} \times 9 \mathrm{~cm})$ over silica gel using stepwise gradient solvents of hexanes/acetone (10:0, 9:1. 8:2, 7:3, 6:4. 5:5, and 0:10; each $1 \mathrm{~L}$ ), and $100 \% \mathrm{MeOH}(1 \mathrm{~L})$ to obtain fifteen fractions (fractions 21FA-21FO). Fraction 21FI ( $318.0 \mathrm{mg})$ was separated using sephadex LH-20 $(50 \mathrm{~cm} \times 2 \mathrm{~cm})$ with elution of $100 \%$ $\mathrm{MeOH}$ to afford compounds $\mathbf{1}(39.7 \mathrm{mg}), \mathbf{2}(74.1 \mathrm{mg})$, and 3 (28.2 mg). Compounds 1-3 were further purified by chromatographic method over reverse-phased silica gel column $(4 \mathrm{~cm} \times 10 \mathrm{~cm})$ using a $\mathrm{H}_{2} \mathrm{O} / \mathrm{MeOH}(40: 60 \rightarrow 10: 90, v / v$, each $100 \mathrm{~mL})$ gradient system. The spectral data for the isolated and reacted compounds were added as Supplementary Materials.

\subsection{1. (3R,5R)-3,5-dihydroxydecanoic acid (1)}

Colorless oil. $[\alpha]_{D}^{25}+37.4(c 0.1, \mathrm{MeOH}) ;{ }^{1} \mathrm{H}-\mathrm{NMR}\left(\mathrm{CDCl}_{3}, 500 \mathrm{MHz}\right) \delta 4.66(1 \mathrm{H}$, dddd, $J=11.0,7.9$, 5.3, 3.0 Hz, H-5), $4.33(1 \mathrm{H}, \mathrm{q}, J=3.7 \mathrm{~Hz}, \mathrm{H}-3), 2.67(1 \mathrm{H}, \mathrm{dd}, J=17.7,4.9 \mathrm{~Hz}, \mathrm{H}-2 \mathrm{a}), 2.58(1 \mathrm{H}, \mathrm{ddd}, J=$ 17.7, 3.7, $1.7 \mathrm{~Hz}, \mathrm{H}-2 \mathrm{~b}), 1.93(1 \mathrm{H}, J=$ dddd, 14.4, 3.8, 3.0, $1.7 \mathrm{~Hz}, \mathrm{H}-4 \mathrm{a}), 1.68$ (1H, ddd, J = 14.4, 11.0, 3.0 Hz, H-4b), 1.65 (1H, m, H-6b), 1.55 (1H, sep, J = 5.3 Hz, H-6a), 1.46 (1H, dddt, $J=10.2,8.0,5.3,2.9 \mathrm{~Hz}$, $\mathrm{H}-7 \mathrm{a}), 1.35$ (1H, dddd, $J=12.7,10.2,8.0,5.3, \mathrm{H}-7 \mathrm{~b}), 1.27\left(2 \mathrm{H}, \mathrm{m}, \mathrm{H}_{2}-9\right), 1.25\left(2 \mathrm{H}, \mathrm{m}, \mathrm{H}_{2}-8\right), 0.85(3 \mathrm{H}, \mathrm{t}, J$ $\left.=6.9 \mathrm{~Hz}, \mathrm{H}_{3}-10\right) ;{ }^{13} \mathrm{C}-\mathrm{NMR}\left(\mathrm{CDCl}_{3}, 125 \mathrm{MHz}\right) \delta 171.1$ (C-1), 76.1 (C-5), 62.5 (C-3), 38.5 (C-2), 35.7 (C-4), 35.4 (C-6), 31.5 (C-8), 24.5 (C-7), 22.5 (C-9), 13.9 (C-10); HMBC correlations (CDCl 3 , H-\# $\rightarrow$ C-\#) H-5 $\rightarrow$ $\mathrm{C}-3, \mathrm{C}-4$, and C-7; H-3 $\rightarrow$ C-1, C-4, and C-5; H-2 $\rightarrow$ C-1, C-3, and C-4; H-4 $\rightarrow$ C-2 and C-3; H-6 $\rightarrow$ C-4, C-5, C-7, and C-8; H-7 $\rightarrow$ C-5, C-6, C-8, and C-9; H-8 $\rightarrow$ C-9 and C-10; H-8 $\rightarrow$ C-9; H-10 $\rightarrow$ C-8 and C-9; (+) HRFABMS obsd $m / z, 187.1331\left[\mathrm{M}-\mathrm{H}_{2} \mathrm{O}+\mathrm{H}\right]^{+}$, calcd for $\mathrm{C}_{10} \mathrm{H}_{19} \mathrm{O}_{3}, 187.1329$.

\subsection{2. (3R,5R)-3-(((3R,5R)-3,5-dihydroxydecanoyl)oxy)-5-hydroxydecanoic acid (2)}

Colorless oil. $[\alpha]_{D}^{25}+1.8($ c $0.1, \mathrm{MeOH}) ;{ }^{1} \mathrm{H}$ and ${ }^{13} \mathrm{C}-\mathrm{NMR}$, see Table $1 ; \mathrm{HMBC}$ correlations $\left(\mathrm{CDCl}_{3}\right.$, $\mathrm{H}-\# \rightarrow \mathrm{C}-\#) \mathrm{H}-3 \rightarrow \mathrm{C}-1, \mathrm{C}-1^{\prime}, \mathrm{C}-2, \mathrm{C}-4$, and C-5; H-5 $\rightarrow \mathrm{C}-3, \mathrm{C}-4, \mathrm{C}-6$, and C-7; H-3' $\rightarrow \mathrm{C}-1^{\prime}, \mathrm{C}-2^{\prime}$, and $\mathrm{C}-5^{\prime} ; \mathrm{H}-5^{\prime} \rightarrow \mathrm{C}-3^{\prime}, \mathrm{C}-4^{\prime}, \mathrm{C}-6^{\prime}$, and C-7'; H-2 $\rightarrow \mathrm{C}-1, \mathrm{C}-3$, and C-4; H-2' $\rightarrow \mathrm{C}-1^{\prime}, \mathrm{C}-3^{\prime}$, and C-4'; H-4a $\rightarrow$ $\mathrm{C}-2$ and C-3; H-4b $\rightarrow$ C-2, C-3, and C-5; H-6 $\rightarrow$ C-4, C-5, and C-7; $\mathrm{CH}_{3} \rightarrow \mathrm{C}-8, \mathrm{C}-8^{\prime}, \mathrm{C}-9$, and C-9' ; (+) HRFABMS obsd $m / z, 373.2590\left[\mathrm{M}-\mathrm{H}_{2} \mathrm{O}+\mathrm{H}\right]^{+}$, calcd for $\mathrm{C}_{20} \mathrm{H}_{37} \mathrm{O}_{6}, 373.2585$.

3.3.3. (3R,5R)-3-(((3R,5R)-5-(((3R,5R)-3,5-dihydroxydecanoyl)oxy)-3-hydroxydecanoyl)oxy)-5hydroxydecanoic acid (3)

Colorless oil. $[\alpha]_{D}^{25}-5.1(c 0.1, \mathrm{MeOH}) ;{ }^{1} \mathrm{H}$ and ${ }^{13} \mathrm{C}-\mathrm{NMR}$, see Table $1 ; \mathrm{HMBC}$ correlations $\left(\mathrm{CDCl}_{3}, \mathrm{H}-\#\right.$ $\rightarrow \mathrm{C}-\#) \mathrm{H}-3 \rightarrow \mathrm{C}-1, \mathrm{C}-1^{\prime}, \mathrm{C}-2, \mathrm{C}-4$, and C-5; H-5' $\rightarrow \mathrm{C}-1^{\prime \prime}, \mathrm{C}-3^{\prime}, \mathrm{C}-4^{\prime}, \mathrm{C}-6^{\prime}$ and C-7'; H-3" $\rightarrow \mathrm{C}-1^{\prime \prime}, \mathrm{C}-2^{\prime \prime}$, and C-5"; $\mathrm{H}-3^{\prime} \rightarrow \mathrm{C}-1^{\prime} ; \mathrm{H}-5^{\prime \prime} \rightarrow \mathrm{C}-4^{\prime \prime}, \mathrm{C}-6^{\prime \prime}$, and C-7"'; H-2a and H-2b $\rightarrow \mathrm{C}-1, \mathrm{C}-3$, and C-4; H-2' a and $\mathrm{H}-2^{\prime} \mathrm{b} \rightarrow \mathrm{C}-1^{\prime}, \mathrm{C}-3^{\prime}$, and C-4'; H-2"a and H-2"b $\rightarrow \mathrm{C}-1^{\prime \prime}, \mathrm{C}-3^{\prime \prime}$, and C-4"; $\mathrm{H}-4 \mathrm{a}$ and $\mathrm{H}-4 \mathrm{~b} \rightarrow \mathrm{C}-3$ and C-5; $\mathrm{H}-4 \mathrm{a}^{\prime}$ and $\mathrm{H}-4 \mathrm{~b}^{\prime} \rightarrow \mathrm{C}-3^{\prime}$ and $5^{\prime} ; \mathrm{H}-4 \mathrm{a}^{\prime \prime}$ and $\mathrm{H}-4 \mathrm{~b}^{\prime \prime} \rightarrow \mathrm{C}-3^{\prime \prime}$ and $5^{\prime \prime} ;(+)$ HRFABMS obsd $m / z$, 581.3657 [M $\left.-\mathrm{H}_{2} \mathrm{O}+\mathrm{Na}\right]^{+}$, calcd for $\mathrm{C}_{30} \mathrm{H}_{54} \mathrm{O}_{9} \mathrm{Na}$, 581.3660.

\subsection{Chemical Synthesis for Structure Determination}

\subsubsection{Acid Hydrolysis of Compounds 2 and 3}

Each $10 \mathrm{mg}$ of compounds 2 and 3 in methanol $(1 \mathrm{~mL})$ was stirred for $1 \mathrm{~h}$ at $60^{\circ} \mathrm{C}$ after $2 \mathrm{~mL}$ of 1 $\mathrm{N} \mathrm{HCl}$ was added. $1 \mathrm{~N}$ aqueous $\mathrm{NaOH}$ was added to the reaction mixture for neutralization, followed by extraction with EtOAc ( $3 \mathrm{~mL})$, and the EtOAc extract was subjected to column chromatography 
over silica gel $(4 \mathrm{~cm} \times 10 \mathrm{~cm})$ using a gradient system of hexane and acetone $(2 \%, 4 \%, 6 \%, 8 \%$, and $10 \%)$ to afford 2a (3,5-dihydroxydecanoic acid methyl ester; hydrolysate of $\mathbf{2}), \mathbf{2 b}$ (3, 5-dihydroxydecanoic acid; hydrolysate of 2), 3a (3,5-dihydroxydecanoic acid methyl ester; hydrolysate of 3 ), and $3 \mathbf{b}$ (3,5-dihydroxydecanoic acid; hydrolysate of 3).

2a and 3a: ${ }^{1} \mathrm{H}-\mathrm{NMR}\left(300 \mathrm{MHz}, \mathrm{CDCl}_{3}\right): \delta 4.26(1 \mathrm{H}$, quintet, $\mathrm{J}=6.3 \mathrm{~Hz}, \mathrm{H}-3), 3.85(1 \mathrm{H}, \mathrm{dd}, \mathrm{J}=7.7,4.1 \mathrm{~Hz}$, H-5), $3.70\left(3 \mathrm{H}, \mathrm{s}, \mathrm{OCH}_{3}\right), 2.51\left(2 \mathrm{H}, \mathrm{m}, \mathrm{H}_{2}-2\right), 1.55(2 \mathrm{H}, \mathrm{m}, \mathrm{H}-4$ and $6 \mathrm{a}), 1.40(2 \mathrm{H}, \mathrm{m}, \mathrm{H}-6 \mathrm{~b}$ and 7$), 1.28$ $\left(4 \mathrm{H}, \mathrm{m}, \mathrm{H}_{2}-8\right.$ and 9), $0.89\left(3 \mathrm{H}, \mathrm{t}, \mathrm{J}=6.6 \mathrm{~Hz}, \mathrm{H}_{3}-10\right) .{ }^{13} \mathrm{C}-\mathrm{NMR}\left(75 \mathrm{MHz}, \mathrm{CDCl}_{3}\right): \delta 172.9(\mathrm{C}-1), 72.3(\mathrm{C}-3)$, 69.1 (C-5), $51.8\left(\mathrm{OCH}_{3}\right), 42.2$ (C-2), 41.5 (C-4), 37.8 (C-6), 31.8 (C-8), 25.0 (C-7), 22.6 (C-9), 14.0 (C-10).

2b and 3b: ${ }^{1} \mathrm{H}-\mathrm{NMR}\left(300 \mathrm{MHz}, \mathrm{CDCl}_{3}\right): \delta 4.66(1 \mathrm{H}, \mathrm{dtd}, \mathrm{J}=11.3,5.0,3.8 \mathrm{~Hz}, \mathrm{H}-5), 4.37(1 \mathrm{H}$, quintet, $\mathrm{J}=$ $3.8 \mathrm{~Hz}, \mathrm{H}-3), 2.72(1 \mathrm{H}, \mathrm{dd}, \mathrm{J}=17.7,5.0 \mathrm{~Hz}, \mathrm{H}-2 \mathrm{a}), 2.61$ (1H, ddd, J = 17.7, 3.8, 1.6, H-2b), 1.93 (1H, dtd, J $=14.4,3.8,1.6 \mathrm{~Hz}, \mathrm{H}-4 \mathrm{a}), 1.76(1 \mathrm{H}, \mathrm{ddd}, \mathrm{J}=14.4,11.3,3.8 \mathrm{~Hz}, \mathrm{H}-4 \mathrm{~b}), 1.68(1 \mathrm{H}, \mathrm{m}, \mathrm{H}-6 \mathrm{a}), 1.55$ (1H, m, H-6b), 1.46 (1H, m, H-7a), 1.35 (1H, m, H-7b), 1.31 (2H, m, H-8), $1.24(2 \mathrm{H}, \mathrm{m}, \mathrm{H}-9), 0.92$ (3H, t, J = 6.7 $\mathrm{Hz}, \mathrm{H}-10)$.

\subsubsection{Synthesis of 1,3-diol-acetonides for Compounds $\mathbf{1}, \mathbf{2}$, and 3}

Each of the purified compounds $\mathbf{1}, \mathbf{2} \mathbf{a}$, and $\mathbf{2} \mathbf{b}$ as well as and mixture of $\mathbf{3 a}$ and $\mathbf{3 b}(5 \mathrm{mg})$ were dissolved in 2,2-dimethoxypropane $(5 \mathrm{~mL})$ and methanol $(1 \mathrm{~mL})$, followed by addition of pyridinium- $p$-toluenesulfonate $(5 \mathrm{mg})$. The mixture was stirred for $12 \mathrm{~h}$ at $25^{\circ} \mathrm{C}$ for the reaction. After quenching with $5 \%$ aqueous $\mathrm{NaHCO}_{3}$, the reaction mixture was extracted with $\mathrm{CH}_{2} \mathrm{Cl}_{2}$ three times. The $\mathrm{CH}_{2} \mathrm{Cl}_{2}$ soluble fraction was evaporated in vacuo and further purified by silica gel column $(4 \mathrm{~cm} \times$ $10 \mathrm{~cm})$ using a gradient solvent system of n-hexane and acetone $(2 \%, 4 \%, 6 \%, 8 \%$, and $10 \%)$ to afford 1 a (acetonide product of $\mathbf{1}$ ), 2c (acetonide product of $\mathbf{2 a}$ ), $\mathbf{2 d}$ (acetonide product of $\mathbf{2 b}$ ), and $3 \mathbf{c}$ (acetonide product of $3 \mathbf{a}$ and $\mathbf{3 b}$ ).

Acetonide derivatives of 1, hydrolysates of 2 and 3 (1a, 2c, and 3c)

${ }^{1} \mathrm{H}-\mathrm{NMR}\left(300 \mathrm{MHz}_{\mathrm{CDCl}}\right.$ ): $\delta 4.27(1 \mathrm{H}, \mathrm{dtd}, J=11.6,6.5,2.5 \mathrm{~Hz}, \mathrm{H}-3), 3.79(1 \mathrm{H}, \mathrm{m}, \mathrm{H}-5), 3.66(3 \mathrm{H}$, $\left.\mathrm{s}, \mathrm{OCH}_{3}\right), 2.53(1 \mathrm{H}, \mathrm{dd}, J=15.6,6.8 \mathrm{~Hz}, \mathrm{H}-2 \mathrm{a}), 2.36(1 \mathrm{H}, \mathrm{dd}, J=15.6,6.2 \mathrm{~Hz}, \mathrm{H}-2 \mathrm{~b}), 1.57(1 \mathrm{H}, \mathrm{dt}, J=$ 12.6, $2.4 \mathrm{~Hz}, \mathrm{H}-4 \mathrm{a}), 1.42\left(3 \mathrm{H}, \mathrm{s}, \mathrm{CH}_{3}\right), 1.34\left(3 \mathrm{H}, \mathrm{s}, \mathrm{CH}_{3}\right), 1.25(6 \mathrm{H}, \mathrm{m}), 0.90\left(3 \mathrm{H}, \mathrm{t}, J=6.8 \mathrm{~Hz}, \mathrm{H}_{3}-10\right)$. ${ }^{13} \mathrm{C}-\mathrm{NMR}\left(75 \mathrm{MHz}, \mathrm{CDCl}_{3}\right): \delta 171.5(\mathrm{C}-1), 98.7$ (OCO), $68.8(\mathrm{C}-3), 65.9(\mathrm{C}-5), 51.6\left(\mathrm{OCH}_{3}\right), 41.3(\mathrm{C}-2)$, 36.5 (C-4), 36.3 (C-6), $31.8(\mathrm{C}-8), 30.1\left(\mathrm{CH}_{3}\right), 24.6(\mathrm{C}-7), 22.6(\mathrm{C}-9), 19.7\left(\mathrm{CH}_{3}\right), 14.0(\mathrm{C}-10)$.

\subsubsection{Deprotection of 1,3-diol-acetonide for Compound 3c}

Acetonide product (3c) in $\mathrm{MeOH}(2 \mathrm{~mL})$ was stirred for $2 \mathrm{~h}$ at $40^{\circ} \mathrm{C}$ for the reaction after adding pyridinium- $p$-toluenesulfonate $(5 \mathrm{mg})$. The reaction mixture was extracted with $\mathrm{CH}_{2} \mathrm{Cl}_{2}$ two times. The $\mathrm{CH}_{2} \mathrm{Cl}_{2}$ soluble fraction was evaporated in vacuo and further purified by silica gel column $(4 \mathrm{~cm} \times$ $10 \mathrm{~cm})$ using a gradient solvent system of n-hexane and acetone $(2 \%, 4 \%, 6 \%, 8 \%$, and $10 \%)$ to afford $3 \mathrm{~d}$.

\subsubsection{Mosher's Esterification of 1, 2, and 3d}

Mosher's esterifications of compounds 1, 2, and 3d were performed in NMR solvents using $(S)$ - and (R)-MTPA [ $\alpha$-methoxy- $\alpha$-(trifluoromethyl)phenyl-acetyl] chloride. Each compounds 1, 2, and $3 \mathrm{~d}(1 \mathrm{mg})$ in pyridine- $d_{5}(0.5 \mathrm{~mL})$ were treated with $(R)-\mathrm{MTPA}-\mathrm{Cl}$ or $(S)-\mathrm{MTPA}-\mathrm{Cl}(6.0 \mu \mathrm{L})$ and 4-(dimethylamino)-pyridine (one crystal). The vials containing reaction mixtures were immediately sealed and shaken for the reaction. Treatments of each compound with (R)-MTPA-Cl afforded (S)-MTPA ester, and vice versa. After being put at room temperature for one hour, the solutions were moved to NMR tube then monitored by ${ }^{1} \mathrm{H}-\mathrm{NMR}$.

(S)-MTPA ester of 1: ${ }^{1} \mathrm{H}-\mathrm{NMR}\left(500 \mathrm{MHz}\right.$, Pyridine-d $\left.\mathrm{d}_{5}\right): \delta 5.776(1 \mathrm{H}$, quintet, $\mathrm{J}=4.1 \mathrm{~Hz}, \mathrm{H}-3), 4.562$ (ddt, $\mathrm{J}=11.5,7.6,3.7 \mathrm{~Hz}, \mathrm{H}-5), 3.239(1 \mathrm{H}, \mathrm{dd}, \mathrm{J}=17.8,5.4 \mathrm{~Hz}, \mathrm{H}-2 \mathrm{a}), 3.029(1 \mathrm{H}, \mathrm{dd}, \mathrm{J}=17.8,3.8 \mathrm{~Hz}, \mathrm{H}-2 \mathrm{~b})$, $2.228(1 \mathrm{H}, \mathrm{d}, \mathrm{J}=15.0 \mathrm{~Hz}, \mathrm{H}-4 \mathrm{a}), 2.009$ (1H, ddd, J = 15.0, 11.3, $3.6 \mathrm{~Hz}, \mathrm{H}-4 \mathrm{~b}), 1.554(1 \mathrm{H}, \mathrm{m}), 1.439$ (1H, $\mathrm{m}), 1.342(1 \mathrm{H}, \mathrm{m}), 1.201(\mathrm{~m}), 1.103(\mathrm{~m}), 0.747\left(3 \mathrm{H}, \mathrm{t}, \mathrm{J}=7.1 \mathrm{~Hz}, \mathrm{H}_{3}-10\right)$. 
(R)-MTPA ester of 1: ${ }^{1} \mathrm{H}-\mathrm{NMR}\left(500 \mathrm{MHz}\right.$, Pyridine- $\left.d_{5}\right): \delta 5.764(1 \mathrm{H}$, quintet, $J=3.9 \mathrm{~Hz}, \mathrm{H}-3), 4.305(1 \mathrm{H}$, $\mathrm{ddt}, 11.6,7.7,3.6 \mathrm{~Hz}, \mathrm{H}-5), 3.255(1 \mathrm{H}, \mathrm{dd}, J=17.9,5.3 \mathrm{~Hz}, \mathrm{H}-2 \mathrm{a}), 3.119(1 \mathrm{H}, \mathrm{dd}, J=17.9,3.8 \mathrm{~Hz}, \mathrm{H}-2 \mathrm{~b})$, $2.111(1 \mathrm{H}, \mathrm{d}, J=15.0 \mathrm{~Hz}, \mathrm{H}-4 \mathrm{a}), 1.927(1 \mathrm{H}, \mathrm{ddd}, J=15.0,11.4,3.3 \mathrm{~Hz}, \mathrm{H}-4), 1.500(1 \mathrm{H}, \mathrm{m}), 1.366(1 \mathrm{H}, \mathrm{m})$, $1.278(\mathrm{~m}), 1.124\left(\mathrm{~m}, 1.065(\mathrm{~m}), 0.756\left(3 \mathrm{H}, \mathrm{t}, J=7.1 \mathrm{~Hz}, \mathrm{H}_{3}-10\right)\right.$.

(S)-MTPA ester of 2: ${ }^{1} \mathrm{H}-\mathrm{NMR}\left(500 \mathrm{MHz}\right.$, Pyridine- $\left.\mathrm{d}_{5}\right): \delta 5.957(1 \mathrm{H}, \mathrm{ddq}, \mathrm{J}=9.7,6.6,3.5 \mathrm{~Hz}, \mathrm{~m}, \mathrm{H}-3$ ), $5.497(1 \mathrm{H}$, quintet, $\mathrm{J}=6.3 \mathrm{~Hz}, \mathrm{H}-5), 5.378\left(1 \mathrm{H}, \mathrm{dq}, \mathrm{J}=5.5,3.6 \mathrm{~Hz}, \mathrm{H}-3^{\prime}\right), 4.628(1 \mathrm{H}, \mathrm{ddd}, \mathrm{J}=15.1,7.3,3.7$ Hz, H-5'), $3.132(1 \mathrm{H}, \mathrm{dd}, \mathrm{J}=16.8,3.5 \mathrm{~Hz}, \mathrm{H}-2 \mathrm{a}), 3.049$ (1H, dd, J = 17.7, 5.5 Hz, H-2a' $), 2.904(1 \mathrm{H}, \mathrm{dd}, \mathrm{J}$ $=16.8,9.0 \mathrm{~Hz}, \mathrm{H}-2 \mathrm{~b}), 2.800\left(1 \mathrm{H}, \mathrm{ddd}, \mathrm{J}=17.9,3.7,1.6 \mathrm{~Hz}, \mathrm{H}-2 \mathrm{~b}^{\prime}\right), 2.471(1 \mathrm{H}, \mathrm{dt}, \mathrm{J}=14.4,6.5 \mathrm{~Hz}, \mathrm{H}-4 \mathrm{a})$, $2.253(1 \mathrm{H}, \mathrm{ddd}, \mathrm{J}=14.3,7.2,5.7 \mathrm{~Hz}, \mathrm{H}-4 \mathrm{~b}), 2.100\left(1 \mathrm{H}, \mathrm{d}, \mathrm{J}=14.0, \mathrm{H}-4 \mathrm{a}^{\prime}\right), 1.859(1 \mathrm{H}, \mathrm{ddd}, \mathrm{J}=14.9,11.6$, $\left.3.6 \mathrm{~Hz}, \mathrm{H}-4 \mathrm{~b}^{\prime}\right), 1.600(1 \mathrm{H}, \mathrm{m}, 1.473(1 \mathrm{H}, \mathrm{m}), 1.423(1 \mathrm{H}, \mathrm{m}), 1.196(\mathrm{~m}), 0.814(6 \mathrm{H}, \mathrm{m})$.

(R)-MTPA ester of 2: ${ }^{1} \mathrm{H}-\mathrm{NMR}\left(500 \mathrm{MHz}\right.$, Pyridine-d $\left.\mathrm{d}_{5}\right): \delta 6.017(1 \mathrm{H}, \mathrm{m}, \mathrm{H}-3), 5.480(1 \mathrm{H}$, quintet, $\mathrm{J}=3.9$ Hz, H-5), 5.374 (1H, dq, J = 12.0, 6.5 Hz, H-3'), $4.682\left(1 \mathrm{H}, \mathrm{ddd}, \mathrm{J}=11.1,7.6,3.5 \mathrm{~Hz}, \mathrm{H}-5^{\prime}\right), 3.319(1 \mathrm{H}, \mathrm{dd}$, $\mathrm{J}=16.8,3.6 \mathrm{~Hz}, \mathrm{H}-2 \mathrm{a}), 3.153\left(1 \mathrm{H}, \mathrm{d}, \mathrm{J}=5.4 \mathrm{~Hz}, \mathrm{H}-2 \mathrm{a}^{\prime}\right), 3.039(1 \mathrm{H}, \mathrm{dd}, \mathrm{J}=16.5,3.8 \mathrm{~Hz}, \mathrm{H}-2 \mathrm{~b}), 2.948(1 \mathrm{H}$, $\left.\mathrm{dd}, \mathrm{J}=16.9,3.0 \mathrm{~Hz}, \mathrm{H}-2 \mathrm{~b}^{\prime}\right), 2.433(1 \mathrm{H}, \mathrm{dt}, \mathrm{J}=13.8,6.6 \mathrm{~Hz}, \mathrm{H}-4 \mathrm{a}), 2.191(1 \mathrm{H}, \mathrm{dt}, \mathrm{J}=13.8,6.6 \mathrm{~Hz}, \mathrm{H}-4 \mathrm{~b})$, $2.121\left(1 \mathrm{H}, \mathrm{d}, \mathrm{J}=14.9 \mathrm{~Hz}, \mathrm{H}-4 \mathrm{a}^{\prime}\right), 1.876\left(1 \mathrm{H}, \mathrm{ddd}, \mathrm{J}=14.9,11.4,3.5 \mathrm{~Hz}, \mathrm{H}-4 \mathrm{~b}^{\prime}\right), 1.612(1 \mathrm{H}, \mathrm{m}), 1.468(1 \mathrm{H}$, m), $1.306(1 \mathrm{H}, \mathrm{m}), 1.156(\mathrm{~m}), 0.821(3 \mathrm{H}, \mathrm{t}, \mathrm{J}=6.9 \mathrm{~Hz}), 0.785(3 \mathrm{H}, \mathrm{t}, \mathrm{J}=6.8 \mathrm{~Hz})$.

(S)-MTPA ester of 3d: ${ }^{1} \mathrm{H}-\mathrm{NMR}\left(500 \mathrm{MHz}\right.$, Pyridine- $\left.\mathrm{d}_{5}\right): \delta 5.899(1 \mathrm{H}, \mathrm{td}, \mathrm{J}=10.0,5.3 \mathrm{~Hz}, \mathrm{H}-3), 5.481$ $(1 \mathrm{H}$, quintet, $\mathrm{J}=6.5 \mathrm{~Hz}, \mathrm{H}-5), 3.309(1 \mathrm{H}, \mathrm{dd}, \mathrm{J}=16.5,3.8 \mathrm{~Hz}, \mathrm{H}-2 \mathrm{a}), 2.449(1 \mathrm{H}, \mathrm{dd}, \mathrm{J}=13.8,6.5 \mathrm{~Hz}, \mathrm{H}-4 \mathrm{a})$, $2.220(1 \mathrm{H}, \mathrm{dt}, \mathrm{J}=13.8,6.5 \mathrm{~Hz}, \mathrm{H}-4 \mathrm{~b}), 1.810(2 \mathrm{H}, \mathrm{m}), 0.812(3 \mathrm{H}, \mathrm{t}, \mathrm{J}=6.5 \mathrm{~Hz}, \mathrm{H}-10)$.

(R)-MTPA ester of 3d: ${ }^{1} \mathrm{H}-\mathrm{NMR}\left(500 \mathrm{MHz}\right.$, Pyridine- $\left.\mathrm{d}_{5}\right): \delta 5.983(1 \mathrm{H}, \mathrm{ddt}, \mathrm{J}=10.2,6.3,3.8 \mathrm{~Hz}, \mathrm{H}-3)$, $5.374(1 \mathrm{H}$, quintet, J = 6.3 Hz, H-5), $3.195(1 \mathrm{H}, \mathrm{dd}, \mathrm{J}=16.5,4.0 \mathrm{~Hz}, \mathrm{H}-2 \mathrm{a}), 2.415(1 \mathrm{H}, \mathrm{dt}, \mathrm{J}=13.8,6.8 \mathrm{~Hz}$, H-4a), $2.166(1 \mathrm{H}, \mathrm{dt}, \mathrm{J}=13.8,6.8 \mathrm{~Hz}, \mathrm{H}-4 \mathrm{~b}), 1.642(2 \mathrm{H}, \mathrm{m}), 0.781(3 \mathrm{H}, \mathrm{t}, \mathrm{J}=6.5 \mathrm{~Hz}, \mathrm{H}-10)$.

\subsection{Biological Activity Evaluation}

\subsubsection{Antibacterial Assay}

The antibacterial activity was evaluated by the broth microdilution method [19]. Four bacterial strains (Escherichia coli ATCC 11775, Staphylococcus aureus ATCC 6538, Bacillus subtilis ATCC 6633, and Pseudomonas aeruginosa) were cultured on Mueller-Hinton (MH) agar plates for $24 \mathrm{~h}$ at $24{ }^{\circ} \mathrm{C}$ (for $B$. subtilis ATCC 6633) or $37^{\circ} \mathrm{C}$ (for three other strains). The bacterial colonies were suspended in $\mathrm{MH}$ broth and cultured for $24 \mathrm{~h}$ at 24 or $37^{\circ} \mathrm{C}$ with $220 \mathrm{rpm}$. The bacterial suspension was diluted with MH broth with $0.5 \mathrm{McF}$ arland turbidity equivalents. Gentamicin (128 $\mu \mathrm{g}$, positive control) and the compounds 1-3 (128 $\mu \mathrm{g}$, respectively) were dissolved in DMSO $(12 \mu \mathrm{L})$ and diluted with $488 \mu \mathrm{L}$ of MH broth to prepare stock solution. One hundred microliter of the stock solution were transferred to a well of 96-well plate and serially diluted by using two-fold dilutions. The bacterial suspension $(50 \mu \mathrm{L})$ was added to each well and the concentrations of test compounds were $128 \mu \mathrm{g} / \mathrm{mL}$. The 96-well plate was incubated for $16 \mathrm{~h}$ at 24 or $37^{\circ} \mathrm{C}$.

\subsubsection{Cytotoxicity}

MCF-7 human breast cancer cell line was obtained from American Typr Culture Collection (ATCC, Manassas, VA, USA) and cultured in RPMI1640 medium (Cellgro, Manassas, VA, USA) supplemented with 10\% FBS (Gibco BRL, Grand Island, NY, USA), $100 \mu \mathrm{g} / \mathrm{mL}$ streptomycin, and $100 \mathrm{U} / \mathrm{mL}$ penicillin. Cultures were maintained at $37^{\circ} \mathrm{C}$ in a humidified incubator with $95 \%$ air and $5 \% \mathrm{CO}_{2}$. The Ez-Cytox cell viability detection kit (Daeil Lab Service Co., Seoul, South Korea) was used for quantification of cell viability. MCF-7 cells were seeded in 96-well plates $\left(1 \times 10^{4}\right.$ cells per well) for $24 \mathrm{~h}$ and treated for the indicated concentrations of test samples in RPMI1640 medium. The Ez-Cytox reagents were added to each well and the absorbance values at $450 \mathrm{~nm}$ was measured using a microplate reader (PowerWave XS; Bio-Tek Instruments, Winooski, VT, USA). 


\section{Conclusions}

An endophytic yeast, Aureobasidium pullulans AJF1, was isolated from flowers of the Aconitum carmichaeli in this study and cultivated on a large scale for chemical investigation. Extensive chemical investigation of the extracts resulted in isolation of three lipid type compounds (1-3). They were (3R,5R)-3,5-dihydroxydecanoic acid unit or the esterified complexes of the unit. Relative and absolute stereochemistries of the isolated compounds (1-3) were established using modified Mosher's method together with analysis of NMR data for their acetonide derivatives. Even though compounds 2 and 3 were all unique lipid type new compounds, they did not show potent antibiotic activities against Escherichia coli, Staphylococcus aureus, Bacillus subtilis, Pseudomonas aeruginosa, and no cytotoxicities against MCF-7 cancer cells. Regardless of their low potencies of activities, it is a good finding that endophytes from medicinal plants could be good sources for new chemistries.

Supplementary Materials: The following are available online. ${ }^{1} \mathrm{H}$ and ${ }^{13} \mathrm{C}-\mathrm{NMR}$ spectra for $1-3$.

Author Contributions: Isolation, structure elucidation, chemical reaction, and manuscript writing, H.G.C.; Isolation of compounds, J.W.K.; Antibiotic assay, H.C.; Cytotoxicity assay, K.S.K.; supervision and project administration, S.H.S.

Funding: This research was supported by National Research Foundation of Korea (NRF-2018R1A2B6001733 and NRF-2019R1A4A1020626).

Conflicts of Interest: The authors declare no conflict of interest.

\section{References}

1. Hirsch, G.; Braun, U. Communities of Parasitic Microfungi: Handbook of Vegetation Science; Kluwer Academic Publisher: Dordrecht, The Netherlands, 1992; pp. 225-250.

2. Rosenblueth, M.; Martínez-Romero, E. Bacterial Endophytes and Their Interactions with Hosts. Mol. Plant Microbe Interact. 2006, 19, 827-837. [CrossRef] [PubMed]

3. Azevedo, J.L.; Maccheroni, W.; Pereira, J.O.; Araujo, W.L. Endophytic microorganisms: A review on insect control and recent advances on tropical plants. Electron. J. Biotechnol. 2000, 31, 15-16. [CrossRef]

4. Muramatsu, D.; Iwai, A.; Aoki, S.; Uchiyama, H.; Kawata, K.; Nakayama, Y.; Nikawa, Y.; Kusano, K.; Okabe, M.; Miyazaki, T. $\beta$-Glucan Derived from Aureobasidium pullulans Is Effective for the Prevention of Influenza in Mice. PLoS ONE 2012, 7, e41399. [CrossRef] [PubMed]

5. Price, N.P.J.; Manitchotpisit, P.; Vermillion, K.E.; Bowman, M.J.; Leathers, T.D. Structural characterization of novel extracellular liamocins (mannitol oils) produced by Aureobasidium pullulans strain NRRL 50380. Carbohydr. Res. 2013, 370, 24-32. [CrossRef] [PubMed]

6. Cao, W.; Qi, B.; Zhao, J.; Qiao, C.; Su, Y.; Wan, Y.J. Control strategy of pH, dissolved oxygen concentration and stirring speed for enhancing $\beta$-poly (malic acid) production by Aureobasidium pullulans ipe-1. Chem. Technol. Biotechnol. 2013, 88, 808-817. [CrossRef]

7. Zain, M.E.; Awaad, A.S.; Razak, A.A.; Maitland, D.J.; Khamis, N.E.; Sakhawy, M.A. Secondary Metabolites of Aureobasidium Pullulans Isolated from Egyptian Soil and Their Biological Activity. J. Appl. Sci. Res. 2009, 5, 1582-1591.

8. Zhou, K.; Tang, L.; Zhou, X.; Wang, T.; Kou, Z.; Wang, Z. A review on phytochemistry and pharmacological activities of the processed lateral root of Aconitum carmichaelii Debeaux. J. Ethnopharmacol. 2015, 160, 173-193. [CrossRef] [PubMed]

9. Strobel, G.; Daisy, B.; Castillo, U.; Harper, J. Natural Products from Endophytic Microorganisms. J. Nat. Prod. 2004, 67, 257-268. [CrossRef] [PubMed]

10. Stierle, A.; Strobel, G.; Stierle, D. Taxol and taxane production by Taxomyces andreanae, an endophytic fungus of Pacific yew. Science 1993, 260, 214-216. [CrossRef] [PubMed]

11. Wu, S.; Huang, R.; Miao, C.; Chen, Y. Two New Steroids from an Endophytic Fungus Phomopsis sp. Chem. Biodivers. 2013, 10, 1276-1283. [CrossRef] [PubMed]

12. Ma, K.; Shen, X.; Huang, R.; Wang, T.; Xie, X.; Liu, S.; Wu, S.; He, J. Bioactive Metabolites Produced by the Endophytic Fungus Phomopsis sp. YM355364. Nat. Prod. Commun. 2014, 9, 669-670. [CrossRef] [PubMed] 
13. Zhang, S.; Huang, R.; Li, F.; Wei, H.; Fang, X.; Xie, X.; Lin, D.; Wu, S.; He, J. Antiviral anthraquinones and azaphilones produced by an endophytic fungus Nigrospora sp. from Aconitum carmichaeli. Fitoterapia 2016, 112, 85-89. [CrossRef] [PubMed]

14. Kurosawa, T.; Sakai, K.; Nakahara, T.; Oshima, Y.; Tabuchi, T. Extracellular Accumulation of the Polyol Lipids, 3,5-Dihydroxydecanoyl and 5-Hydroxy-2-decenoyl Esters of Arabitol and Mannitol, by Aureobasidium sp. Biosci. Biotech. Biochem. 1994, 58, 2057-2060. [CrossRef]

15. Rychnovsky, S.D.; Rogers, B.N.; Richardson, T.I. Configurational Assignment of Polyene Macrolide Antibiotics Using the [13C]Acetonide Analysis. Acc. Chem. Res. 1998, 31, 9-17. [CrossRef]

16. Su, B.N.; Park, E.J.; Mbwambo, Z.H.; Santarsiero, B.D.; Mesecar, A.D.; Fong, H.H.S.; Pezzuto, J.M.; Kinghorn, A.D. New Chemical Constituents of Euphorbia quinquecostata and Absolute Configuration Assignment by a Convenient Mosher Ester Procedure Carried Out in NMR. J. Nat. Prod. 2002, 65, 1278-1282. [CrossRef] [PubMed]

17. Salunke, G.B.; Shivakumar, I.; Gurjar, M.K. Total synthesis of verbalactone: An efficient, carbohydrate-based approach. Tetrahedron Lett. 2009, 50, 2048-2049. [CrossRef]

18. Doshida, J.; Hasegawa, H.; Onuki, H.; Shimidzu, N. Exophilin A, a new antibiotic from a marine microorganism Exophiala pisciphila. J. Antibiot. 1996, 49, 1105-1109. [CrossRef] [PubMed]

19. Wiegand, I.; Hilpert, K.; Hancock, R.E. Agar and broth dilution methods to determine the minimal inhibitory concentration (MIC) of antimicrobial substances. Nat. Protoc. 2008, 3, 163-175. [CrossRef] [PubMed]

Sample Availability: Samples of the compounds are not available from the authors.

(C) 2019 by the authors. Licensee MDPI, Basel, Switzerland. This article is an open access article distributed under the terms and conditions of the Creative Commons Attribution (CC BY) license (http://creativecommons.org/licenses/by/4.0/). 